\title{
AVOCADO SEEDS (Persea americana Mill.): FORMULATIONS OF ELIXIR VARIED BY SOLVENTS COMPOSITION
}

\author{
Septia Andini ${ }^{\left.a^{*}\right)}$, Lusi Indriani ${ }^{a}$, Erni Rustiani ${ }^{a}$ \\ ${ }^{a)}$ Universitas Pakuan, Bogor, Indonesia \\ Corresponding Author: septiaandini85@gmail.com
}

Article history: received 08 December 2019; revised 17 January 2020; accepted 25 February 2020

\begin{abstract}
Kidney stones disease is asignificant health problem in the world and Indonesia is no exception. Traditionally, avocado seeds can be used as a laxative medicine for kidney stones disease. Elixiris a clear and sweet hidroalkohol solution intended for oral use and a flavor is usually added to enhance the taste. This study was to determine theformula of the avocado seed elixir which has the best quality and the level of flavonoids.Elixir testing was performedusing several methods such as organoleptic, limpidity, viscosity, $\mathrm{pH}$ and specific weightas well as total flavonoids. The result showed that the best elixir formula was the Formula I which composed of 7\%avocado seed extract, 5\% ethanol, $10 \%$ propylene glycol, $40 \%$ sirupus simplex, $0.1 \%$, essence mint and 100\%aquadestilata ad. Furthermore, Elixirhad a brown color, mint aroma and pretty sweettaste. The test results showed that elixir had a viscosity of $7.92 \mathrm{cP}$; $\mathrm{pH}$ of 5.65; specific weight of $1.0413 \mathrm{~g} / \mathrm{mL}$ andtotal flavonoids of $2.1020 \%$.
\end{abstract}

Keywords: kidney stones; avocado seeds; elixir; flavonoids.

\section{INTRODUCTION}

Kidney stone disease is a significant health problem in the world and Indonesia is no exception. In 2013, the prevalence of patients which diagnosed kidney stonesby physician interviews in Indonesia amounted to 0.6 percent of the 250 million population [1]. Traditional treatment is oftenconsidered as an alternative ways, so that a lot of research is focused on potential plants which possibly contains certain chemical compounds that have a laxative effect on kidney stones. Laxative activity of flavonoids can help kidney to remove kidney stones through urine, while potassium can degrade calcium and bindswith oxalate so that its solubility in water increases (Nisma [2]).

Avocado (Persea americana Mill.) family Lauraceae is used in this study. Traditionally, avocado seeds can be used as a laxative medicine for kidney stones disease. A research by Adliah [3] showed that the water extract of avocado seedswith concentration of $1050 \mathrm{mg} / 100 \mathrm{ml}$ is the highest dose to dissolve calcium oxalate in kidney stones with the highest potassium levels of $0.035 \%$. On the other hand,the result of phytochemical test of avocado seeds extracts showed that the avocado seed contains polyphenols, flavonoids, triterpenoids, quinones, saponins, tannins and monoterpenoid as well as sesquiterpenoids (Zuhrotun [4], 2007).

Avocado seeds extract is insoluble in water because it contains a quite high starch, approximately of 23\% (Winarti [5]). Therefore, to improve its solubility, an elixir was provided. The purposes of the elixir preparation were to improve the solubility of important substances, to guarantee the homogeneity, to easily absorbed important substances in dissolved forms, to make the taste sweeter and have better aroma, andto easilyusedby people who havedifficulties to swallow drugs such as children andelderly. Elixir product is not widely distributed in the market. Therefore, there is a needs to make an elixir of herbalin order to facilitate peoples in the treatment of kidney stones. Elixir has the advantages that the solutions is clear and does not need to be shaken compared to suspension.

Solvents used in the preparation of the elixir were $70 \%$ ethanol, propylene glycol, and water which aimed to increase the solubility of the elixir. Anief [6] states that the concentration of solvents in the preparation of elixir is typically $5-10 \%$ of alcoholand $10-25 \%$ of propylene glycol (Rowe [7]).

\section{RESEARCH METHODS}

\section{Materials}

Avocado seeds (Persea americana Mill) obtained from juice traders around Universitas Pakuan Bogor, 70\% ethanol (Brataco Chemical), Propylene glycol (Brataco Chemical), essence mint (Brataco Chemical), aquadestilata (Brataco Chemical), Sodium Acetate 1M (Merck®), Quercetin (Sigma Aldrich®), $\mathrm{AlCl}_{3}$ 10\% (Merck®).

\section{Produced of Avocado Seeds Dry Extract}

Ripe avocado seeds were cleaned of dirt, washed and dried in an oven at $50^{\circ} \mathrm{C}$. Once dried, seeds weregrinded and sieved using a sieve mesh 30 . Extraction were prepared by using stew. A total of 100 grams of powder simplicia was 
put into a pot with $1 \mathrm{~L}$ of water, boiled for 15 minutes, startsafter the temperature reached $90^{\circ} \mathrm{C}$ and stir up occasionally. Filter the water while hot through batiste, then put in a flask (initial treatment).Then, avocado seeds residue was added with $1 \mathrm{~L}$ of water, treat as same as the initial treatment. Finally, a filtrate is generated [8]. The liquid filtrate wasused to get dry extract using a vacuum dryer with a temperature of $60^{\circ} \mathrm{C}$.

\section{Formulation of Elixir}

Elixir was made with a concentration of $1.05 \mathrm{~g} / 15 \mathrm{~mL}$ (one drink). Elixirwas made as much as $150 \mathrm{~mL}(10.5 \mathrm{~g}$ avocado seeds extract) according to the research of Adliah [3] which usesa laxative of kidney stones with a concentration of $1050 \mathrm{mg} / 100 \mathrm{~mL}$. Elixir was made using 3 formulas with different solvent composition.

The materials used in this study were weigh according to the formula. Avocado seeds extract were dissolved in $70 \%$ ethanol in a separate place,then propylene glycol was dissolved with water. Afterwards, both materials were mixed using a homogenizer. The mixture was filtered and put in a beaker and added with sirupus simplex. Essence mint in water solution was added. Finally, distilled water were add into the beaker and gently stir up the solution. Then put into a measuring cup of $200 \mathrm{~mL}$ and transferred into containers of $150 \mathrm{~mL}$ (Helmi [9]).

\section{Elixir Testing}

\section{a. Organoleptic test}

Organoleptic test was carried out in the elixir to directly assess the product which comprising of taste, color and aroma before packaged.

\section{b. Limpidity test}

Limpidity test was performed by using a centrifuge, which aimed to look for sediment in the elixir.

\section{c. Viscosity and Flow test}

Viscosity test was done by using a brookfield viscometer.

\section{d. pH test}

PH test was performed by using a $\mathrm{pH}$ meter calibrated with standard buffer $\mathrm{pH} 4$ and $\mathrm{pH}$ 7. Measurements were done at room temperature with a $\mathrm{pH}$ condition of elixirbetween 5-7 (Connors [10]).

\section{e. Specific Weight test}

Measurement of specific weight was performed by using a pycnometer.

\section{Determination of Total Flavonoids inAvocado Seeds}

a. Determinationof Maximum Wavelength Quercetin

Absorbance at a wavelength of 380-780 nm was performed using a spectrophotometer (Helpida [11]).

b. Determination of Optimum Incubation Time

Absorbance was measured at the maximum wavelength with different incubation time of 5, 10, 15, 20, 25 and 30 minutesin order to get the optimum stable time [11].

\section{c. Preparation of Standard Curves quercetin}

Elixir was shaken homogenously,left out during the optimum time, and then measured its absorbance at the maximum wavelength [11].

\section{d. Determination of Total Flavonoids}

$100 \mathrm{mg}$ of avocado seeds extract was weighed and then diluted with methanol to $50 \mathrm{~mL}$. Put $10 \mathrm{~mL}$ of the extract into a 50 mLflask using pipette and then added $1 \mathrm{~mL}$ of $10 \%$ aluminum chloride, $1 \mathrm{~mL}$ of $1 \mathrm{M}$ NaAcetate and distilled water. Afterwards, the solution was shaken homogenously, leftout during the optimum time, and absorbance was measured at the maximum wavelength. The absorbance data was inserted into the regression equation of the standard curve quercetin, then calculated the total flavonoid content [11].

\section{e. Determination of Total Flavonoids Elixir of Avocado Seed Extract}

Elixir was weighed which equivalent to $100 \mathrm{mg}$ of avocado seedsextract. Determination of flavonoids in elixir of avocado seed extract (Persea americana Mill) was carried out using the same method of determination of levels of flavonoids in the avocado seed extract (Persea americana Mill) [11].

\section{RESULTS AND DISCUSSION}

\section{Quality Test Results of Elixir}

\section{a. Organoleptic Test Results}

Differences in taste were causedby the variation of solvent concentration. The higher the concentration of solvent, the bitterthe taste of elixir formula. Furthermore, bitter taste in the formula was possibily caused by the characteristics of dry avocado seed extract which had a bitter taste. So that, there was a need to addsweeteners in each elixir formula of the avocado seed.

\section{b. Limpidity Test Results}

Limpidity test was performed by measuring the absorbance of elixir using a spectrophotometer. The results showed that at a wavelength of $430 \mathrm{~nm}$, the value of absorbance was 0.156A at Formula I, 0.222A at Formula II, and $0.238 \mathrm{~A}$ atFormula III. In addition, the smallest value of the absorbance was the Formula I which had the clearestappearance thanFormula II and Formula III. Furthermore, the higher the concentration of solvent,the darker the appearance of the elixir. The darker appearance of the elixir affects the value of absorbance so that each formula produced different absorbance value. Spectrophotometer wasset at a wavelength of $430 \mathrm{~nm}$, based on the resultsof flavonoids levels determination.

Centrifuge test was performed to determine sedimentation level. The results showed that each formula had different level of sedimentation as follows, Formula I was $0.3 \mathrm{~cm}$, Formula II was $0.4 \mathrm{~cm}$ and Formula III was 0.5 $\mathrm{cm}$. These results indicated that Formula I was the best formula due to its smallest amount of sediment than Formula II and Formula III.

c. Viscosity Test and Flow Characteristics Results

The results of viscosity test showed that elixir formula had an average viscosity value as follows,Formula I was $7.92 \mathrm{cP}$, Formula II was $11.56 \mathrm{cP}$, and Formula III was 13.18 $\mathrm{cP}$. The variation of solvent concentrationin each elixir 
formularesulteda different values of viscosity. Furthermore, the results of the flow characteristics showed that the Thixotropic flow was the most excellent flow characterdue to a combination of Plastis and Pseudoplastisflow. The flow characteristics obtained from thixotropic materials relies on rate of increasing and reducing the shearing stress as well as thetime of the sample experienced a rate of shear (Martin, [12]).

\section{d. pH Test Results}

$\mathrm{pH}$ measurement was done by using a $\mathrm{pH}$ meter calibrated with standard buffer $\mathrm{pH} 4$ and $\mathrm{pH} 7$ at room temperature. The results showed that $\mathrm{pH}$ value of Formula I was 5.65, Formula II was 5.72 and Formula III was 5.73. Theseresults indicated that the $\mathrm{pH}$ of each elixir formula satisfied the $\mathrm{pH}$ requirements of elixir which should be range at $\mathrm{pH} 5$ to 7 . The $\mathrm{pH}$ of elixir should meets the $\mathrm{pH}$ of the intestinalbecause the elixir will be absorb in the intestine so that the $\mathrm{pH}$ should be at the same range of the intestinal $\mathrm{pH}$ which usuallyacidic to neutral at 5 to 7 [10]

\section{e. Specific Weight Test Results}

Specific weight is the ratio of the weight of the substance to thevolume of water that weighedat the same temperature [8]. The results showed that the average value of specific weight of the elixir was $1.0460 \mathrm{~g} / \mathrm{mL}$.

\section{Analysis of Total Flavonoids of Dry Seeds Extract and Elixir Formula of Avocado Seed}

The analysis was performed by using UV spectrophotometer at wavelengths420-440 nm. The quercetin standard was provided maximum absorption at a wavelength of $430 \mathrm{~nm}$ with the absorbance was 0.162 .The optimum incubation time was done at 5, 10, 15, 20, 25, and 30 minute. The results showed that the optimum incubation in standard quercetin was stable at20 minuteswith a absorbance value of 0.152 . The relationship between the absorbance and concentration providedan equation of $\mathrm{y}=$ $0.0805 \mathrm{x}-0.0039$ with a correlation coefficient of $\mathrm{r} 2=$ 0.9998 . The total flavonoids of dry avocado seed extract were calculated and the results showed that total flavonoids level of sample was $2.1023 \%$,

The results of total flavonoids in elixir formula was: $2.1020 \%$ in Formula I, 2.1017\% in Formula II and $2.0986 \%$ in Formula III.In addition, the SD value of total flavonoids in elixir formula was 0.00188 . Furthermore, the total flavonoid of elixir formula was lower than dry avocado seed extract, which each formula had different level of decreased amount as follows, Formula I was $0.0143 \%$, Formula II was $0.0285 \%$, Formula III was $0.1759 \%$. These results indicated that the levels of flavonoids in the formula I had a little differences with dryavocado seedextract. The different levels of total flavonoids on each formula was caused by variation of solvent composition.

\section{CONCLUSION}

1. Elixir formula of avocado seedthat have the best quality was Formula I which composed of $7 \%$ avocado seed extract, $5 \%$ ethanol, $10 \%$ propylene glycol, $40 \%$ sirupus simplex, $0.1 \%$ essence mint and $100 \%$ aquadestilata ad.

2. Total flavonoid of dry avocado seed extract was $2.1023 \%$ and elixir was $2.1020 \%$.

\section{REFERENCES}

[1] Kemenkes RI. 2013. Riset kesehatan Dasar. Badan Penelitian dan Pengembangan Kesehatan. Jakarta.

[2] Nisma, Fatimah. dkk. 2011.Pengaruh Suhu dan Waktu Perendaman TerhadapPengurangan Formaldehid dalam Wadah Peralatan Makan Melaminmenggunakan SpektrofotometerUV-VIS. Jurusan Farmasi.FMIPA.UHAMKA. Jakarta : diakses tanggal26 Mei 2011.

[3] Adliah, 2017.Skripsi. Aktivitas Ekstrak Air dan Ekstrak Etanol Biji Alpukat (Persea Americana Mill.) Sebagai Peluruh Batu Ginjal Secara In Vitro. Fakultas Matematika Ilmu dan Pengetahuan Alam Univeritas Pakuan. Bogor.

[4] Zuhrotun, A., 2007, Aktivitas Antidiabetes Ekstrak Etanol Biji Alpukat (Persea americanaMill) Bentuk Bulat, Karya Tulis Ilmiah:Fakultas Farmasi, Universitas Padjajaran Bandung

[5] Winarti, S. dan Purnomo, Y. 2006. Olahan Biji Buah. Trubus Agrisarana, Surabaya.

[6] Anief, M. 2005. Ilmu Meracik Obat. UGM Press : Yogyakarta. 129-131

[7] Rowe, R.C., P.J. Sheskey, and M., E. Quinn. 2009. Handbook of Pharmaceutical Excipients. Lexi-Comp: American Pharmaceutical Association, Inc. 592.

[8] DepKes RI. 1979. Farmakope Indonesia Edisi III. Jakarta. Direktorat Pengawasan Obat dan Makanan. Jakarta. 96, 534, 767.

[9] Helmi, H. 2012. Skripsi.Pengaruh Penambahan Gliserin Terhadap Stabilitas Sediaan Eliksir Dari Ekstrak Rimpang Jeringau Merah (Acorus Sp). Fakultas Kedokteran dan Ilmu Kesehatan Universitas Tanjungpura. Pontianak.

[10] Connors, K.A., Amidon, G.L. and Stella, V.J., 1986, Chemical Stability of Pharmaceutical John Willey and Sons. New York, 3-26, 163-168

[11] Helpida, V. 2016. Skripsi.Formulasi Granul Efervesen Ekstrak Biji Alpukat Dan Daun Salam Dengan Perbedaan Konsentrasi Asam Dan Basa.Fakultas Matematika Ilmu dan Pengetahuan Alam Univeritas Pakuan. Bogor.

[12] Martin, A., Swarbrick, J., Cammarata, A. 1993. Farmasi Fisik Edisi Ketiga Jilid 2. Jakarta: Universitas Indonesia. 